\title{
Molecular mechanism of chromium (VI) Induced Cytotoxicity and Apoptosis in L929 Mouse Fibroblasts Mohamed W. Khalil ${ }^{1}$ and Nadia Raghib Ali Abo-zeid ${ }^{2}$ 1-Zoology Dept. Faculty of science-Fayoum University 2-Fellow in Ain Shams Specialized Hospital, EM lab. Ain Shams University,Cairo, Egypt
}

\section{ABSTRACT}

Several methods were used to investigate the mode of death of L929 mouse fibroblast cells in cultures treated with different concentrations of sodium Chromate. Drastic morphological alterations were showed; the cells have grown chaotic, lost their alignment and adherence to the dish surface, consequently they appeared almost round. The nuclei became bigger, later on fragmented into multi nuclei as indication to apoptosis.

Chromate inhibited the proliferation of L929 cells and led to the increase of free nucleosomes in the cell cytoplasm. The exposure of cells to Chromate for 24 and $48 \mathrm{hrs}$. led to the accumulation of the cells in $\mathrm{G} 2 / \mathrm{M}$. the ratios were 66.5 and $84 \%$ after 24 and $48 \mathrm{hrs}$. respectively. The cells in S phase remained unaffected for $24 \mathrm{hrs}$. and then extensively fall down, may be due to the induction of apoptosis. It was observed that a dose-dependent increase in caspase 3 and caspase 8 activities due to treatment with Chromate. These data are expressed as the fold increase in caspases activities as compared with the control.

Gel electrophoresis of DNA extracted from cells treated with Chromate for $48 \mathrm{~h}$ revealed the discontinuous "ladder" pattern of degradation. Such patterns of DNA degradation generally serve as a marker of apoptosis and indicate a preferential hydrolysis of DNA at the internucleosomal linker regions.

The conclusion of cytometric, microscopic, and biochemical data reported in this study fully supported that $\mathrm{Cr}(\mathrm{VI})$ induces genotoxic and cytotoxic effects including structural and functional DNA damage.

Keywords: Apoptosis, Apoptotic ladder, Caspases- oxidative stress-in vitro-in vivo- superoxide anion hydroxyl radicals - MTT assay - DNA damage - cell cycle analysis

\section{INTRODUCTION}

The cellular responses to carcinogen exposure influence cellular fate, which in turn modulates the neoplastic response. Their responses to genotoxic stress are also believed to provide a protective effect against tumor development by preventing the outgrowth of cells with potential oncogenic alterations. Apoptosis is a tightly regulated form of physiological cell death which is dependent on the expression of cell-intrinsic suicide machinery. The central component of this machinery is a proteolytic system involving a family of proteases called caspases. These enzymes participate in a cascade that is triggered in response to proapoptotic signals and culminates in cleavage of a set of proteins, resulting in disassembly of the cell (Kerr et al., 1994). Prominent morphological changes include cell shrinkage, condensation of the nuclear chromatin, fragmentation of 
the nucleus, and cleavage of chromosomal DNA at internucleosomal sites, resulting in the generation of a characteristic ladder pattern of DNA fragments on electrophoresis. DNA damage may cause cell cycle delay, presumably to provide an opportunity for a cell to repair the lesions before replication (Hartwell and Kastan, 1994). When damage is irreparable, cells must be removed from the proliferating population to control propagation of damaged DNA. The predominant cellular fates, in response to irreparable DNA damage, are terminal growth arrest and apoptosis (Evan and Littlewood, 1998). The responses to genotoxic stress that lead to these cellular fates are mediated largely by p53 (Amundson et al., 1998). The final cellular outcome of p53 activation depends on many factors and is mediated, in part, through the transcriptional activation of downstream effector genes that are involved in cell cycle arrest, DNA repair, and apoptosis (Ford and Hanawalt, 1995 and Smith and Fornace 1996). Blebbing of the cell surface results in the release of membrane bound apoptotic bodies. Phosphatidylserine, which is normally located on the inner face of the plasma membrane, becomes exposed on the outer surface and provides a recognition signal for engulfment by phagocytes (Fadok et al., 1992 and Martin et al., 1995). Thus, apoptosis results in rapid and efficient removal of superfluous or damaged cells.

Hexavalent Chromium (VI) is classified by the International Agency for Research on Cancer as a group I carcinogen. The U.S. Occupational Safety and Health Administration was obliged to reduce the permissible exposure limit (PEL). Cr (VI)containing compounds are widespread in cigarette smoke, automobile emissions, and in the environment (e.g., Cr (VI)-contaminated water). These compounds are commonly used in the chemical industry, artistic paints, anticorrosion paints, alloy cast irons, and wood treatment, electroplating, and stainless steel welding (IARC, 1990; Lurie and Wolfe, 1990). The lower respiratory tract is the target organ of $\mathrm{Cr}$ (VI) exposure, and its accumulation in lung tissue is found in workers with occupational exposure and in cigarette smokers (Hayes, 1998, Gibb et al., 2000, and Luippold et al., 2003).

Epidemiologic studies have consistently shown that occupational exposure to $\mathrm{Cr}$ (VI) is strongly associated with a higher incidence of lung cancer (Langard, 1990 and Nurminen, 2004). Exposure increases the incidence of lung cancer in cigarette smokers (Hu et al., 2004), thus the cancer morbidity rate for smokers who were formerly (Chrome industry) $\mathrm{K}_{2} \mathrm{CrO}_{4}$ workers, with 9 or more years of exposure, is 21.6 times higher than that of nonsmokers (Russo et al., 2005).

However, the cause for cytotoxicity induction is not entirely understood. A series of in vitro and in vivo studies have demonstrated that chromium (VI) induces an oxidative stress through enhanced production of reactive oxygen species (ROS) (Bridgewater et al., 1994). These lead to DNA damage and oxidative deterioration of lipids and proteins, (Bagchi et al., 2001).

A cascade of cellular events occur following chromium (VI)-induced oxidative tress including enhanced production of superoxide anion and hydroxyl radicals, increased lipid peroxidation, enomic DNA fragmentation, modulation of intracellular oxidized states, activation of protein kinase $\mathrm{C}$, and altered gene expression (Xu et al., 1996 and Bagchi et al., 2002).

L929 cell line is a model for in vitro test. It is usually used to test the effects of carcinogenic substances. The objectives of this study were to characterize the effect of $\mathrm{Cr}$ (VI) as a model complex genotoxin on cultivated L 929 mouth fibroblasts and their sensitivity to $\mathrm{Cr}$ (VI)-induced growth arrest. The mechanism of $\mathrm{Cr}$ (IV) to induce cytotoxic and apoptotic effects were also more explored. 


\section{MATERIALS AND METHODS}

\section{Cells and culturing:}

Dulbecco's modified Eagle's medium (DMEM), newborn calf serum, and other cell culture supplements were obtained from Gibco-BRL (Eggenstein, Germany), plastic wares and glass slides from Nunc (Roskilde, Denmark). The chemicals 3-(4,5dimethylthiazol-2-yl)-2,5-diphenyltetrazolium bromide (MTT), Azur B-eosin stain, 4' -6' -di-amidino-2-phenylindole (DAPI), propidium iodide, RNase, camptothecine and other chemical were purchased from Sigma.

Sodium chromate $\left(\mathrm{Na}_{2} \mathrm{CrO}_{4} \cdot 4 \mathrm{H}_{2} \mathrm{O}\right.$. M. wt. 234) was dissolved in deionized $\mathrm{H} 2 \mathrm{O}$ and sterilized by passage through a $0.2 \mu \mathrm{m}$ filter before use. The L929 mouse fibroblasts (ATCC CCL 1, NCTC clone 929 of strain L) were grown in Dulbecco's minimal essential medium supplemented with $2 \mathrm{mM}$ glutamine, $100 \mathrm{U} / \mathrm{ml}$ penicillin/ $100 \mathrm{~g} / \mathrm{ml}$ streptomycin, $0.1 \mathrm{mM}$ non-essential amino acids, $10 \%$ newborn calf serum (NCS). The cultured cells were incubated at $37{ }^{\circ} \mathrm{C}$ in a humidified $5 \% \mathrm{CO}_{2}$ atmosphere.

Counting and assessment of viability were performed by the trypan blue exclusion method, whereby dead cells were stained blue, while viable cells were bright. The percentage of viable cells was calculated by the following formula: Viability $=$ No. of viable (unstained) cells/ total No. of cells [viable + dead (stained) $x 100$.

\section{Cell proliferations and cell morphology}

The L929 mouse fibroblasts were grown to near confluency on glass coverslips (13 $\mathrm{mm}$ in diameter). After $48 \mathrm{hrs}$, the indicated concentrations of sodium Chromate (6$12 \mu \mathrm{M})$ were added and the cells were incubated for an additional $24 \mathrm{hrs}$. The cells were fixed with Azur B-Eosin in methanol 1:15 (v: v) before the staining with Azur B-Eosin solution.

For the staining of cell nuclei the cells were fixed and then incubated for 30 minutes with $0.5 \mu \mathrm{g} / \mathrm{ml}$ of 4'-6'-di-amidino-2-pheny lindole (DAPI). After removal of the staining mixture, the cells were washed 3 times with cold PBS. For fluorescence microscopy the glass cover slips were mounted on slides with Vecta-Shield (Vector Laboratories, Burlingame, CA, USA) and then examined under a Zeiss Axiophot fluorescence microscope.

\section{Growth inhibition assay}

Cells were seeded in 96 well plates at $4 \times 10^{3}$ cells/well and treated with various concentrations of sodium Chromate for $48 \mathrm{hrs}$. Growth inhibition was assessed by MTT assay. Briefly, following treatment of the cells, the medium was replaced with fresh medium containing $0.5 \mathrm{mg} / \mathrm{ml}$ MTT [3-(4, 5-dimethyl-2-thiazolyl)-2,5-diphenyl-2Htetrazolium bromide] solution and the plates were incubated in a dark room for $4 \mathrm{hrs}$. At the end of incubation, the medium was removed, the water-insoluble MTT-formazan crystals were dissolved in $\mathrm{HCl}(0.4 \mathrm{M})$ in isopropanol. The reduction of MTT was determined at $595 \mathrm{~nm}$ using a (Titertek multiscan) photometer.

\section{Flow cytometric measurement}

Cells $\left(3 \times 10^{6}\right)$ were treated with test substance $10 \mu \mathrm{M}$ for $48 \mathrm{hrs}$. and then fixed in $80 \%$ cold methanol for $30 \mathrm{~min}$ and washed twice with PBS. After the cells have been washed with $0,1 \%$ saponine, they were incubated with propidium iodide $40 \mathrm{~g} / \mathrm{ml}$ and RNase $100 \mathrm{~g} / \mathrm{ml}$ ) at $37^{\circ} \mathrm{C}$ for $30 \mathrm{~min}$ (Taylor, 1980; Zong et al., 1994). The fluorescence represented the amounts of propidium iodide bound with the cell DNA were analysed by 
flow-cytometric analysis. The samples were measured with Cellfit facScan instrument (Becton Dickinson immunocytometry System). The fluorescence of individual cells irradiated with at a wavelength of $360 \mathrm{~nm}$. The data was analyzed with the computer program ModFit LT.

Apoptosis detection by ELISA

The detection of apoptosis by this method is based on a quantification of the enrichment of mono- and oligo-nucleosomes in the cytoplasm by Cell Death Detection (Enzyme-Linked ImmunoSorbent Assay) ELISA kit (Boehringer-Mannheim). Briefly, $1 \times 10^{4}$ cells in $200 \mu 1$ of medium were incubated for $12 \mathrm{hrs}$. with different concentrations of test substance or positive control substance camptothecine. The cells were collected by centrifugation and lysed. The supernatant containing the cytoplasmic histone-associated DNA fragments was transferred to a microplate coated with streptavidin, and then reacted with a mixture of the anti-histone antibodies labelled with biotin, and anti-DNA antibodies coupled with peroxidase. The substrate of peroxidase was thereafter added and development of the colour was read photometrically at $405 \mathrm{~nm}$ against $490 \mathrm{~nm}$ as background. The specific enrichment of mono- and oligo-nucleosomes released into the cytoplasm was expressed as enrichment factor compared with the control.

\section{Assay activities of caspase-3 and caspase-8}

Activities of Caspases were assayed using their specific substrates Ac-IE-pNA (Acetyl-Ile-Glu-Thr-Asp-pnitroanaline) for caspase 8 and AC-DEVD-pNA (Acetyl-AspGlu-Val-Asp-p-nitroalanine) for caspase 3 . Briefly, semi confluent cells $\left(5 \times 10^{5}\right)$ were incubated with RPMI-1640MEM medium containing various concentrations of sodium Chromate for 8 hours. The cells were lyzed using $80 \mu 1$ of ice-cold lysis buffer containing $50 \mathrm{mM}$ HEPES, $5 \mathrm{mM}$ CHAPS, $5 \mathrm{mM}$ DTT and $0.1 \mathrm{mM}$ EDTA, $\mathrm{pH} 7.4$ and put on ice for $5 \mathrm{~min}$, followed by centrifugation at $10000 \mathrm{~g}$ for $15 \mathrm{~min}$ at $4^{\circ} \mathrm{C}$. Twenty microliters of the supernatant was added to $100 \mu \mathrm{l}$ assay buffer containing $20 \mathrm{mM}$ HEPES, $5 \mathrm{mM}$ CHAPS, 5 mM DTT, 2 mM EDTA, $5 \%$ sucrose, $\mathrm{pH}$ 7.4. Ten microliters of caspase substrate were then added in the reaction system to a final concentration of $0.2 \mathrm{mM}$. The cleavage of the substrate was followed spectrophotometrically at $405 \mathrm{~nm}$ against negative and positive control. The activities were calculated according to the instruction of the manufacturer (Sigma, Kit, Product code CASP8C and CASP3C).

\section{Apoptosis ladder}

The cells at a density of $10^{6}$ were treated with $20 \mu \mathrm{M}$ of sodium Chromate for 24 and $48 \mathrm{hrs}$. and then collected by centrifugation at $2000 \mathrm{xg}$ for $5 \mathrm{~min}$ were collected by centrifugation. The resultant cell pellet was washed in PBS buffer and resuspended in 1 $\mathrm{ml}$ PBS. The DNA was isolated according to the procedure provided with the kit ApopLadder kit purchased from Takara Shuzo Co., Ltd.. DNA sample were transferred to a horizontal $1.2 \%$ agarose gel electrophoresis, performed at $9 \mathrm{~mA}$ for $12 \mathrm{~h}$. After electrophoresis, the gel was stained with ethidium bromide $(1 \mathrm{mg} / \mathrm{ml})$, washed, visualized and photographed by a digital Camera under UV light under U.V.) as described, Gorczyca et al.,1993a and b]

\section{RESULTS AND DISCUSSION}

\section{Effects of $\mathrm{Na}_{2} \mathrm{CrO}_{4}$ on morphology and viability of the cultured cells}

The characteristic of cell growth in the presence of Sodium Chromate provided drastic cell morphological alterations. The treated L929 cells differed from the aligned and closely packed in network fashion control cells (Fig. 1 a). They have grown chaotic, lost their alignment and adherence to the dish surface, so that they appeared almost round. 
The Chromate induced decreased rate of cell growth, increased cell size, and increased ratio of cytoplasm: nucleus, which are typical characteristics of cells progressing toward apoptotic death. The loss of some cytoskeletal elements may be considered as a possible cause of these morphological alterations (Fig. 1b). The nuclei were also affected by Chromate. Their potato shapes were altered, and later on fragmented into multi nuclei (Fig. $1 \mathrm{c}$ and d). This alteration may be considered as an indication for apoptosis.

MTT-test methods showed that the Chromate inhibits the proliferation of L929 cells in a concentration dependent manner at lower concentration $(10 \mu \mathrm{g}$ and $1 \mathrm{mg})$. ( $\mathrm{IC}_{50}$ value after 24 hrs. $)=100 \pm 6 \mu \mathrm{M})($ Fig. 2).

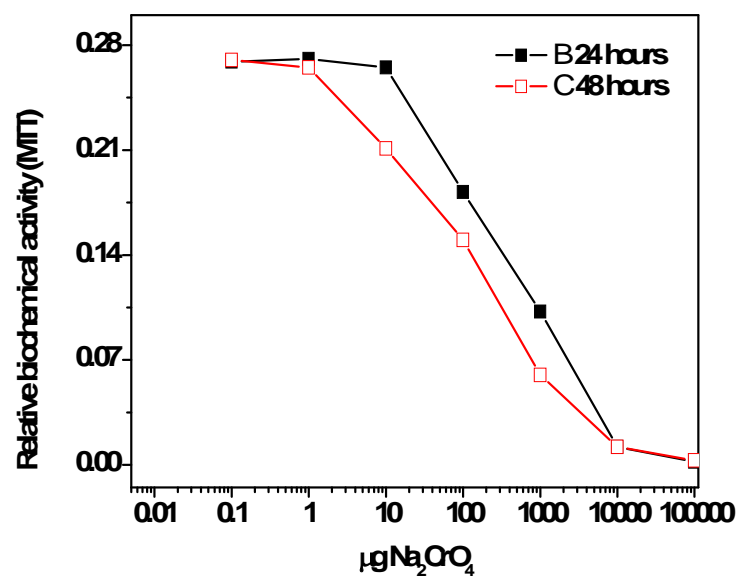

Fig. 2: MTT-test showed the inhibition of $\mathrm{L} 929$ cells proliferation after treatment by Sodium Chromate. $\left(\mathrm{IC}_{50}\right.$ value after 24 hours $)=100 \pm 6 \mu \mathrm{M}$ ).

\section{Induction of apoptosis}

The cells exposed to different concentrations of sodium Chromate or camptothecin as positive control for $12 \mathrm{hrs}$. showed also the apoptotic death. These treatments triggered extensive DNA fragmentation prior to cell death and lead to activation of an endogenous endonuclease that cleaves double stranded DNA at internucleosomal linker region leading to mono- and oligonucleosomes, (Wylie, 1980). Using mouse monoclonal antibodies directed against DNA and histones that allowed specific determination of mono- and oligonucleosomes by sandwich-enzymeimmunoassay. The result in figure 3 revealed that both sodium Chromate and camptothecine lead to increase of nucleosomes in the cell cytoplasm in a concentration dependent manner indicating the induction of apoptosis.

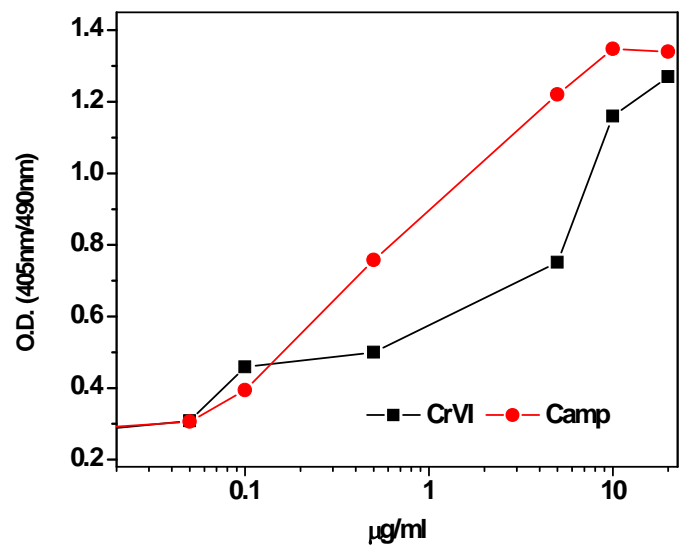


Figure 3: Showed an increase of free nucleosomes in cell cytoplasm after treatment with different concentration of Sodium Chromate. The result indicate apoptosis induction

\section{Cell Cycle Effects}

L929 cells were treated by sodium Chromate for $48 \mathrm{hrs}$., and the DNA content was analyzed by cytometry after staining with propidium iodide (Fig. 4). In control cells, the $\mathrm{G} 1, \mathrm{~S}$, and $\mathrm{G} 2-\mathrm{M}$ populations represented $80,12.5$, and $7.5 \%$ of the cells, respectively (Fig. 4 a). The exposure of the cells to $10 \mu \mathrm{M}$ of Chromate for 24 and $48 \mathrm{~h}$ led to the accumulation of 66.5 and $84 \%$ of the cells in G2 /M respectively. The percent of cells in $\mathrm{S}$ phase remained $24 \mathrm{hrs}$. unaffected and then extensively fall down, may be due to the induction of apoptosis at the second day (S-phase 3.5\%), (Fig. 4 b,c and d)

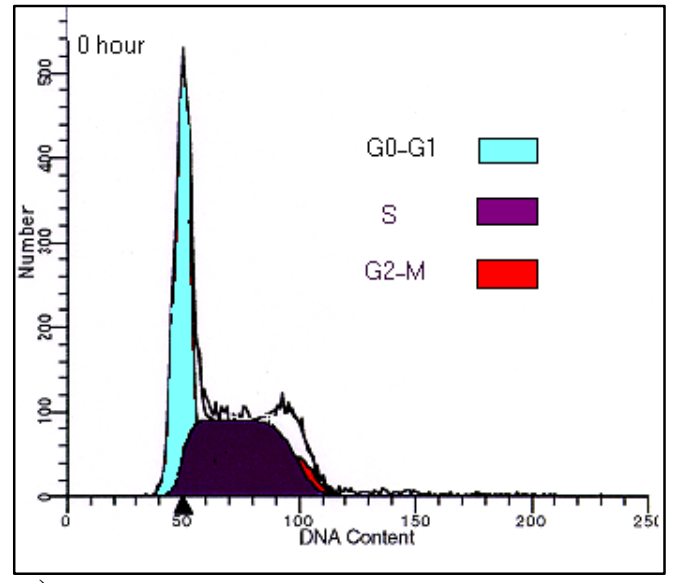

a)

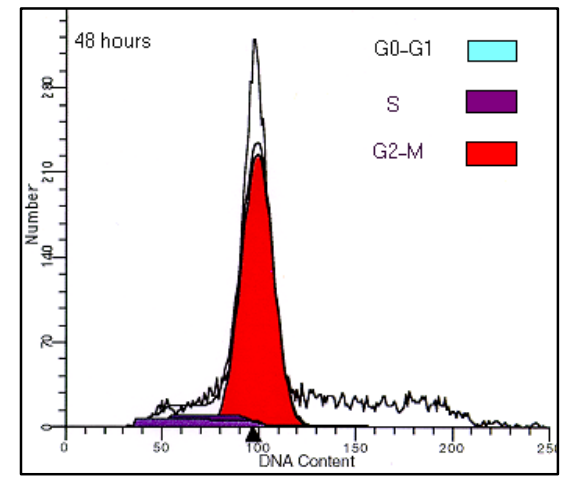

c)

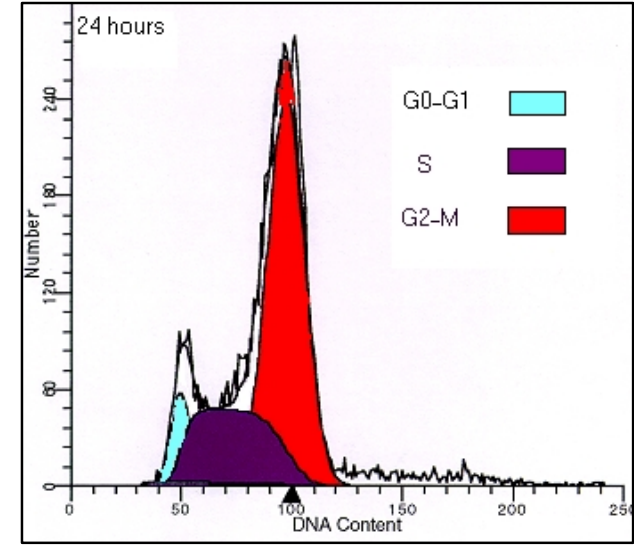

b)

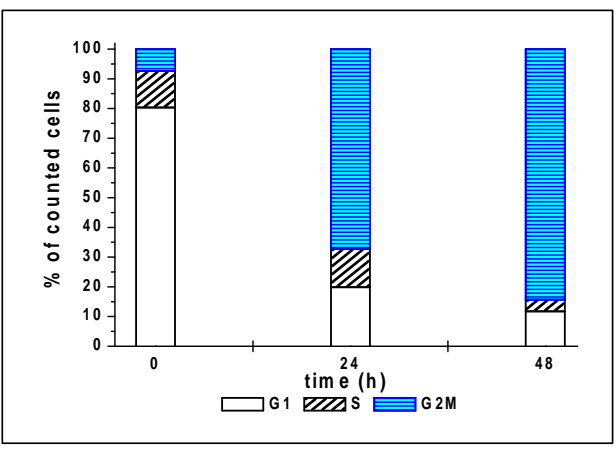

d)

Figure 4: Showed the influence of $10 \mu \mathrm{M}$ Sodium Chromate on the cell cycle of L929 mouse fibroblasts: It showed a high peak in the G0/G1-phase of the control (a). In the presence of Chromate the cells accumulated in the G2/M-phase 24 and $48 \mathrm{~h}$ after incubation (b, c). S phase remained $24 \mathrm{~h}$ unaffected and then extensively fall down. (d) is a representative histogram of DNA content shows the percentages ofG0/G1-, S-, and G2/M phases of cell cycle after addition of Sodium Chromate for 24 and $48 \mathrm{~h}$.

\section{Activity of caspase-3 and caspase-8}

Caspase (Cysteine-requiring Aspartate Protease) are a family of proteases that mediate cell death and are important for the process of apoptosis. Caspase 3 (also referred 
to it as CPP32) is a member of CED-3 subfamily of caspases and is one of the critical enzymes of apoptosis. It is the most studied of mammalian caspases that can process procaspases 2, 6, 7 and 9. It cleaves specifically most of steps related-substrates including many key proteins such as the nuclear enzyme poly (ADP-ribose) polymerase (PARP) (Nicholson et al., 1995). This cleavage is a part of a mechanism leading to cell death. In addition, caspase 3 plays a central role in mediating nuclear apoptosis including chromatin condensation and DNA fragmentation as well as cell blebbing (Vivian et al., 2002). Caspase 8 (known also as Mach 5, MACH, and FLICE) is localized at the top of the hierarchy of the caspases cascade and is a member of the "upstream" or inhibitor family of caspases, (Boldin et al., 1996). Caspases 8 exists in the cell as an inactive proenzyme of $55 \mathrm{kDa}$. It is converted to the active form, consisting of 18 and $12 \mathrm{kDa}$ subunits, upon its recruitment to the cytoplasmic domain of activated death receptors such as Fas, via the adaptor protein FADD (Kischkel et al., 1995 and Medema et al., 1997). The activation of proenzyme is triggered by the protein's aggregation which leads to auto- or transprocessing. Caspase 8 activates downstream caspases (3, 6 and 7) that lead to apoptotic cell death, (Srinivasula et al. 1996; Muzio et al. 1997).

In this work caspases 3 and 8 activation were evaluated in L929 cells exposed to $\mathrm{Na}_{2} \mathrm{CrO}_{4}$ for 8 hours (Fig. 5). It was observed that a dose-dependent increase in caspase 3 and caspase 8 activities was shown. These data are expressed as the fold increase in caspases activities as compared with the control. Results are the means of at least three independent experiments. The activities of caspase 3 and 8 increased to 8 and 10 folds after the treatment with $5 \mu \mathrm{M}$ of Chromate and scored to approximately 25 and 30 folds respectively. This dramatic induction of caspases comparing with untreated control cells suggested that $\mathrm{Cr}(\mathrm{VI})$-induced apoptotic cell death and determined that caspases 3 and 8 participate in its propagation.

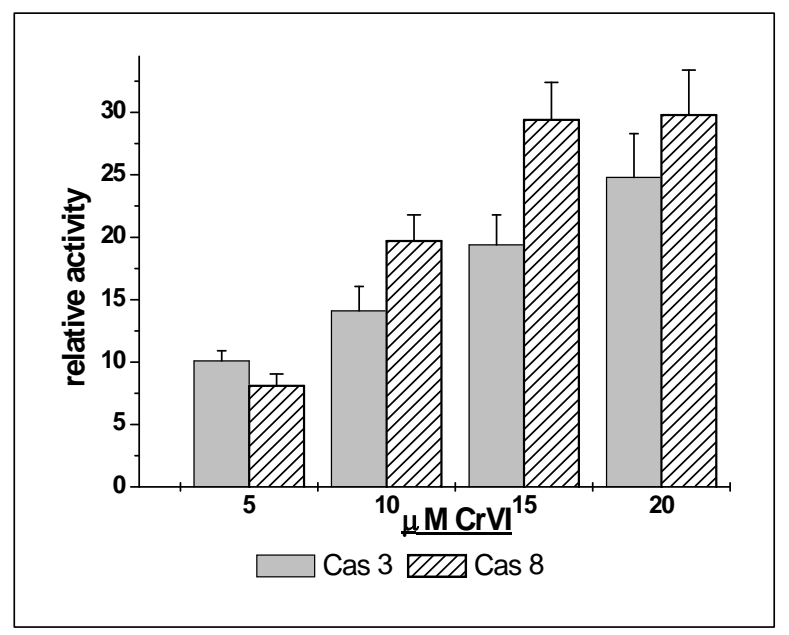

Figure 5: showed the relative increase of caspases-3 and- 8 activities after the treatment of L929-cells with $10 \mu \mathrm{M} \mathrm{Na}_{2} \mathrm{CrO}_{4}$ for 8 hours, a dose-dependent increase in caspase 3 and caspase 8 activities. It was observed that a dose-dependent increase in caspase 3 and caspase 8 activities were induced by the Chromate, .

\section{DNA-Ladder}

Gel electrophoresis of DNA from cells treated with $20 \mu \mathrm{M} \mathrm{Na} 2 \mathrm{CrO}_{4}$ for $48 \mathrm{~h}$ revealed the discontinuous "ladder" pattern of degradation. DNA fragments extracted 
from intact cells were electrophoresed and exhibited a clear ladder pattern in which the smallest fragment is one nucleosome $(180 \mathrm{bp})$ and the size of the other fragments were multiples of $\sim 180$ bp (Fig. 6). This Method confirmed oligonucleosomal DNA fragmentation in the treated cells (Gong et al., 1994). Such discrete cleavage of DNA, generating DNA fragments of a size of mononucleosomes (mononucleosome 180-220 bp in length) and oligonucleosomes, was seen as early as $18-24 \mathrm{~h}$ after exposure to $10 \mu \mathrm{M}$ $\mathrm{Na}_{2} \mathrm{CrO} 4$. Such pattern of DNA degradation generally serves as a marker of apoptosis and indicates a preferential hydrolysis of DNA at the internucleosomal linker regions. The conclusion of the cytometric, microscopic, and biochemical data reported in this study fully supported that $\mathrm{Cr}$ (VI) induces genotoxic and cytotoxic effects including structural and functional DNA damage. This Cr (VI) ion enters cells through an anion transporter, where it undergoes metabolic reduction to reactive genotoxic species (Wetterhahn et al., 1989 and Rossi and Wetterhahn 1989). These products, as well as the oxidative stress generated by the reduction process, lead to these diverse effects.

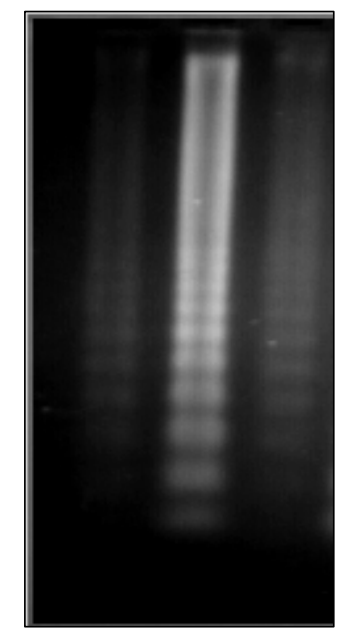

Figure 6: Apoptotic ladder: Electrophoretic pattern of DNA extracted from L929 cells treated with Sodium Chromate $(20 \mu \mathrm{M})$. The low molecular weight DNA extracted was subjected to electrophoresis. Note the bands of DNA observed at regular intervals in lanes. Each band represent multiples of DNA of 180-bp in length.

\section{References}

Amundson, S. A., Myers, T. G., and Fornace, A. J. J. (1998): Roles for p53 in growth arrest and apoptosis: putting on the brakes after genotoxic stress. Oncogene, 17: 3287-3299.

Bagchi, D., Bagchi, M. and Stohs, S.J. (2001): Chromium (VI)-induced oxidative stress, apoptotic cell death and modulation of p53 tumor suppressor gene. Mol. Cell. Biochem. 222(1):149-158.

Bagchi, D., Stohs, S.J, Downs, B.W., Bagchi, M. and Preuss, H. G. (2002): Cytotoxicity and oxidative mechanisms of different forms of chromium. Toxicology, 180: 5-22

Boldin, M.P., Goncharov, T.M., Goltsev, Y.V. and Wallach, D. (1996): Involvement of MACH, a novel MORT1/FADD-interacting protease, in Fas/Apo-1 and TNF receptor-induced cell death. Cell. 85:803.

Bridgewater, L. C., Manning, F. C., and Patierno, S. R. (1994): Base-specific arrest of in vitro DNA replication by carcinogenic chromium: relationship to DNA interstr 
and crosslinking. Carcinogenesis (Lond.), 15: 2421-2427.

Evan, G., and Littlewood, T. (1998): A matter of life and cell death. Science (Wash. DC), 281: 1317-1322.

Fadok, V.A., Voelker, D. R., Campbell, P.A., Cohen, J. J., Bratton, D. L. and Henson, P.M. (1992): Exposure of phosphatidylserine on the surface of apoptotic lymphocytes triggers specific recognition and removal by macrophages. Immunol 148:2207.

Ford, J. M., and Hanawalt, P. C. (1995): Li-Fraumeni syndrome fibroblasts homozygous for p53 mutations are deficient in global DNA repair but exhibit normal transcription-coupled repair and enhanced UV resistance. Proc. Natl. Acad. Sci. USA, 92: 8876-8880.

Hartwell, L. H., and Kastan, M. B. (1994): Cell cycle control and cancer. Science (Wash. DC), 266: 1821-1828.

Gibb HJ, Lees PS, Pinsky PF and Rooney B.C. (2000): Lung cancer among workers in chromium chemical production. AM J Ind Med; 38:115-126.

Gong, J., Traganos, F. and Darzynkiewicz, Z. (1994): A selective procedure for DNA extraction from apoptotic cells applicable for gel electrophoresis and flow cytometry. Anal. Biochem. 218(2): 314-319.

Gorczyca, W., Bigman, K., Mittelman, A., Ahmed, T., Gong, J., Melamed, M. R., and Darzynkiewicz, Z. (1993 a): Induction of DNA strand breaks associated with apoptosis during treatment of leukemias. Leukemia, 7: 659-670.

Gorczyca, W., Gong, J. and Darzynkiewicz, Z. (1993 b): Detection of DNA strand breaks in individual apoptic cells by the in situ terminal deoxynucleotidyl transferase and nick translation assays. Cancer Res. 53; 1945-1951.

Hayes, R.B. (1998): Review of occupational epidemiology of chromium chemicals and respiratory cancer. Sci Total Environ.71:331-339.

Hu, W., Feng, Z. and Tang, M.S. (2004). Chromium (VI) enhances (+/-)-anti7beta,8alpha-dihydroxy-9alpha,10alpha-epoxy-7,8,9,10-

tetrahydrobenzo[a]pyrene-induced cytotoxicity and mutagenicity in mammalian cells through its inhibitory effect on nucleotide excision repair. Biochem. 43:14282-14289.

IARC, (1990): Chromium, nickel and welding. IARC Monogr Eval Carcinog Risks Hum, 49:1-648.

Kerr, J.F.R., Winterford, C.M. and Harmon B.V.(1994): Apoptosis: Its significance in cancer and cancer therapy. Cancer 73:2013

Kischkel, F.C., Hellbardt, S., Behrmann, I., Germer, M., Pawlita, M., Krammer, P.H.and Peter, M.E. (1995): Cytotoxicity-dependent APO-1 (Fas/CD95)-associated proteins from a death-inducing signaling complex (DISC) with the receptor. J.EMBO.,14: 5579-5588.

Langard S. (1990): One hundred years of chromium and cancer: a review of epidemiological evidence and selected case reports. Am. J. Ind. Med. 17: 189-215.

Luippold R.S., Mundt, K.A., Austin, R.P., Liebig, E., Panko, J., Crump, C., Crump, K., Proctor, D. (2003): Lung cancer mortality among Chromate production workers. Occup Environ Med. 60:451- 457.

Lurie, P. and Wolfe, S.M. (1990): Continuing exposure to hexavalent chromium, a known lung carcinogen: an analysis of OSHA compliance inspections, 19902000. Am J Ind Med. 42:378-383. 
Martin, S.J., Reuterlingsperger, C.P., McGahon, A.J., Rader, J.A., van Schie, R.C., LaFace, D.M. and Green, D.R. (1995): Early redistribution of plasma membrane phosphatidylserine is a general feature of apoptosis regardless of the initiating stimulus: Inhibition by overexpression of $b c l-2$ and $a b l$. J. Exp. Med. 182:1545.

Medema, J. P., Scaffidi, C., Kischkel, F. C., Shevchenko, A., Mann, M., Krammer, P. H. and Peter, M. E. (1997): FLICE is activated by association with the CD95 death-inducing signaling complex (DISC). J. EMBO., 16(10): 2794-2804.

Muzio, M., Salvesen, G.S., Dixit, V.M. (1997): FLICE induced apoptosis in a cell-free system. Cleavage of caspase zymogens. J. Biol. Chem. 31; 272(5):2952-2956.

Nurminen M.(2004): On the carcinogenicity risk assessment of chromium compounds. Am. J. Ind. Med. 45:308-309.

Rossi, S.C and Wetterhahn, K.E.1989. Chromium(V) is produced upon reduction of chromate by mitochondrial electron transport chain complexes. Carcinogenesis, 10(5):913-20

Russo, P., Catassi, P., Cesario, A., Imperatori, A., Rotolo, N., Fini, M., Granone, p. and Dominioni, L. (2005): Molecular Mechanisms of Hexavalent Chromium-Induced Apoptosis in Human Bronchoalveolar Cells. Am. J. Resp. Cell and Mol. Biol.33: 589-600.

Smith, M. L., and Fornace, A. J. J. (1996): Mammalian DNA damage-inducible genes associated with growth arrest and apoptosis. Mutat. Res., 340:109-124.

Srinivasula, S.M., Ahmad, M., Fernandes-Alnemri, T., Litwack, G., Alnemri, E.S. (1996):: Molecular ordering of the Fas-apoptotic pathway: the Fas/APO-1 protease Mch5 is a CrmA-inhibitable protease that activates multiple Ced-3/ICElike cysteine proteases. Proc. Natl. Acad. Sci. U S A. 10;93(25):14486-14491.

Taylor, I. W. (1980): A rapid single step staining technique for DNA analysis by flow microfluorimetry, J. Histochem. Cytochem. 28; 102.

Vivian Y. Lee, David S. McClintock, Matthew T. Santore, G. R. Scott Budinger, and Navdeep S. Chandel.: Hypoxia Sensitizes Cells to Nitric Oxide-induced Apoptosis (2002). J. Biol. Chem. 277: (18) 16067-16074.

Wetterhahn, K. E., Hamilton, J. W., Aiyar, J., Borges, K. M., and Floyd, R. (1989): Mechanism of chromium(VI) carcinogenesis. Reactive intermediates and effect on gene expression. Biol. Trace Element Res., 21: 405-411.

Wylie, A. H. (1980): Glucocorticoid-induced thymocyte apoptosis is associated with endogenous endonuclease activation, Nature, 284; 555-556.

Xu, J., Bubley, G. J., Detrick, B., Blankenship, L. J., and Patierno, S. R. (1996): Chromium (VI) treatment of normal human lung cells results in guaninespecific DNA polymerase arrest. DNA-DNA cross-links and S-phase blockade of cell cycle. Carcinogenesis (Lond.), 17: 1511-1517.

Zong Z., Fujikawa K., Kouhei T. Y., Yamagishi H., Tanino M., Odashima S. (1994): Potentiation of K252a, a protein kinase inhibitor_induced polyploidization by cAMP in cultured fibrosarcoma cell line, Biochem. Biophys. Res. Commun. 205(1): 746_750. 


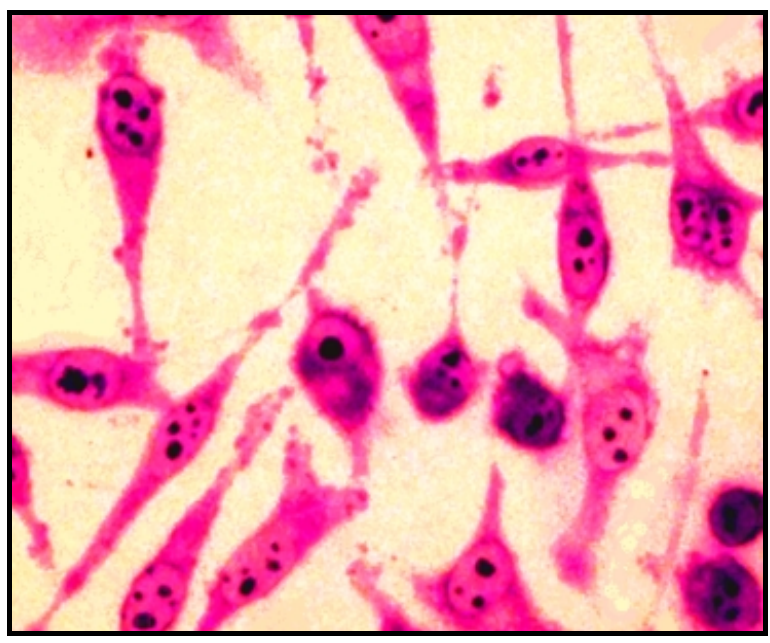

a)

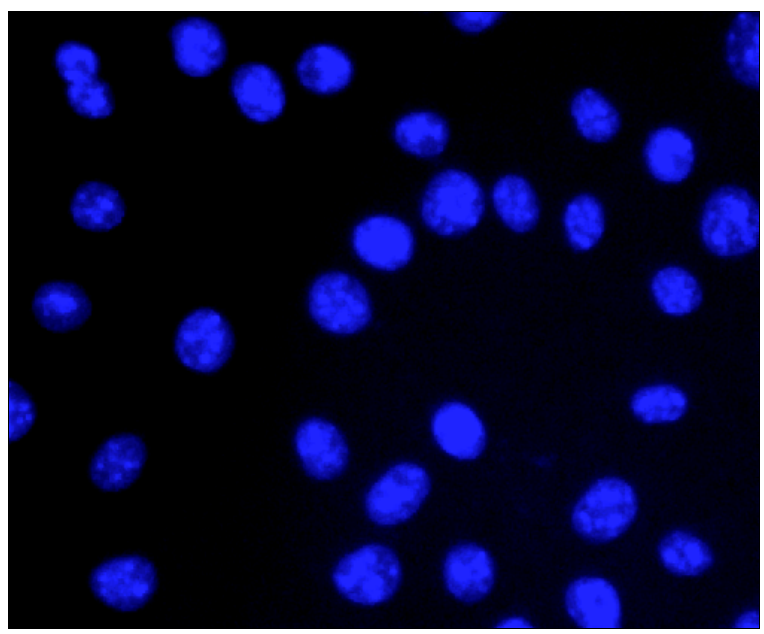

c)

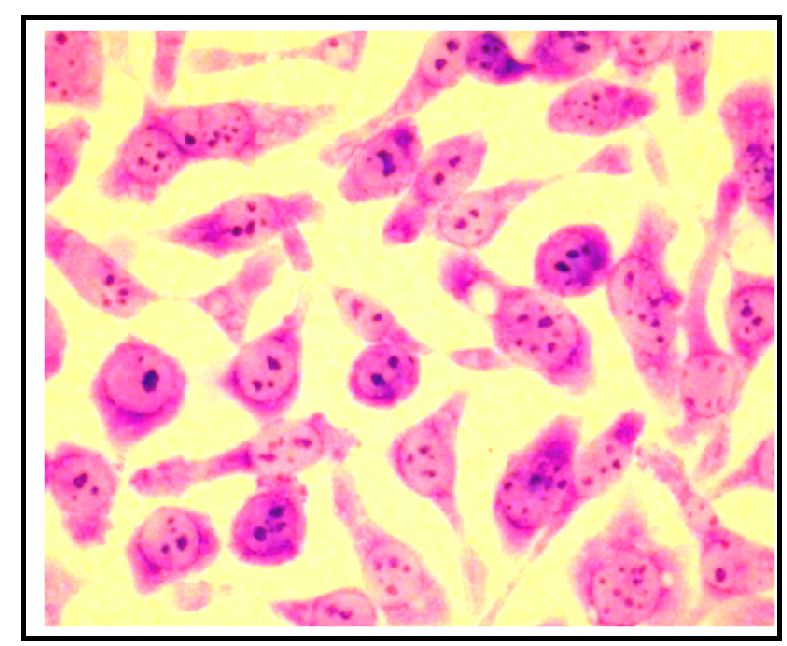

b)

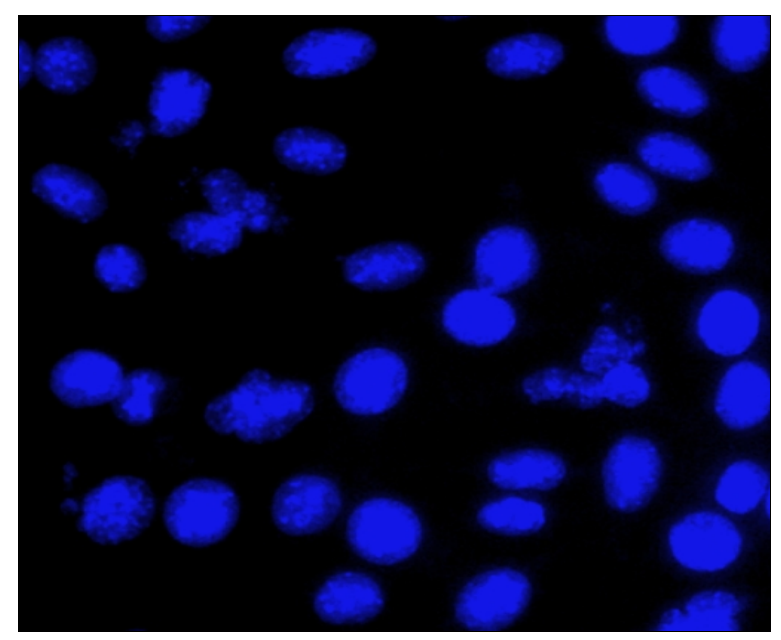

d)

Figure 1: Microscopy of L929 mouse fibroblast cells stained with Azur B-eosin. Cells were grown on glass cover slips in four-well plates, treated with $10 \mu \mathrm{M}$ Sodium Chromate. (a and c) The control sample shows the normal spindle-shape cells network and their nuclei were stained with DAPI viewed by rhodamin filter. ( $b$ and d) The treated cells were showed chaotic fashion, lost their alignment and contact to each other and became more rounded. The shapes of nuclei were also affected and later on fragmented into multi nuclei. 


\title{
التأثير الجزيئي للأيونات الكروم السداسي المسببة للسمية والموت الأبوبتوزي في

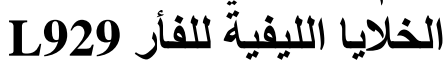

\author{
محمد وسيم محمد خليل1 ــ نادية راغب على ابوزيد2 \\ 1- قسم علم الحيو ان- كلية العلوم جامعة الفيوم

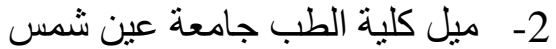

استخدمت عدة وسائل للتحقيق في طريقة موت الخلايا الليفية للفأر -L929 عند تعرضها لأيونات الكروم

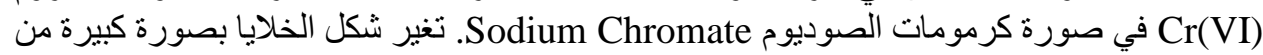

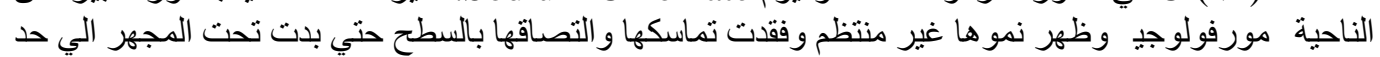

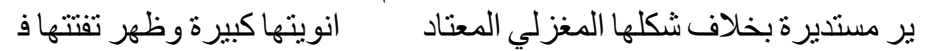
الي طريقة الموت المبرمج للخلايا (أبوبتوزيس).

أظهرت النتائج أيضا توقة الكيرج معدل نمو الخلايا تقريبا إضافة الي زيادة في النيوكلوزومات الحرة في سيتوبلازم الخلية

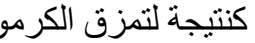

وبدر اسة التأثير علي دورة الخلية وجد أن ألخلايا الباقية على قيد الحياة تفشل في تجاوز مرحلة الإنقسام

الميتوزي وظهرت النسبة متر أكمة في تلك المرحلة حتى بلغت

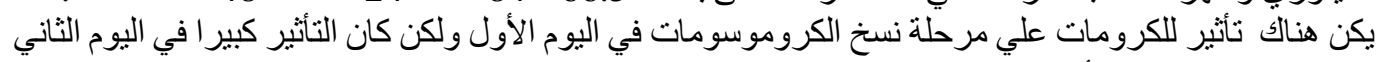

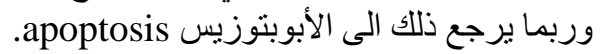

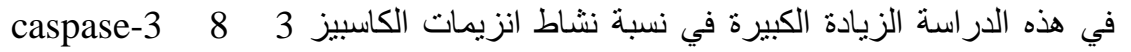

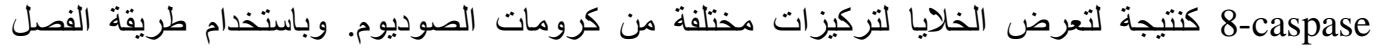

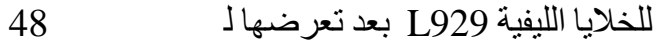

الكهربائي electrophoresis

apoptotic ladder "

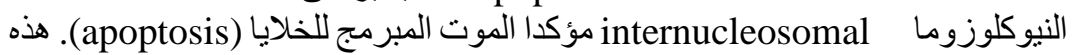

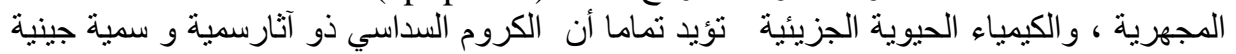

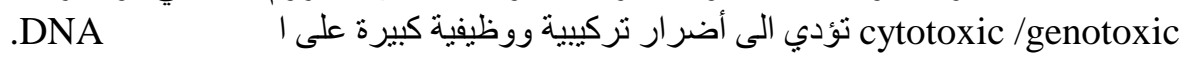

